\title{
Taiwan: Reference Of Good Practices For Latin America In Clean Industry
}

https://doi.org/10.21272/sec.3(2).110-125.2019

\section{Ed. Fernando Alonso Ojeda Castro}

Professor, Business Administration Program, University Piloto of Colombia; Taiwan Economic Development Center (RCTED), National Taiwan University (NCU), Taiwan

\section{Abstract}

The main objective of the research is to show the importance of Taiwan, as a global reference in the environmental theme, with emphasis on "Clean Industry" like a reference for Latin America.

The investigation of the subject of garbage in Taiwan, is carried out in the following logical sequence: first one makes an account of the Conferences / Agreements, that have been developed globally in relation with the environmental issue; In the second part, try to answer the question: why is Taiwan a reference in wage management?

The third part, will be shown the structure achieved today, it is integral to other environmental processes, working with air, to garbage collection, through the back office of companies.

The sources of information were primary and secondary, both national and international, I went several times to observe the same, in such cities Taipei, Zhongly, Taoyuan, in the Campus of the "National Central University", in the course, of 2016.

The research confirms empirical and theoretically, shows that it is possible to structure environmental policies, starting from the basic education of children, where the State is disruptive and leader in this initiative.

Similarly, the Colleges and Universities, observe in this model, the basis of "Green Education", respecting the rules of the Confucius Master, which promotes the balance between man and nature in any activity of man. Finally, it is recommended, as a strategic support for the State, that it sees exclusively, in the Fiscal policy, based on the collection of taxes, as its only, and imperative fiscal balance formula, without realizing that, as in the Taiwanese case, it is possible to establish, promote companies, agencies, capable of continuously investigating, against methods, processes of low or minimum environmental impact, which can be sold to other States or to the Company inside and outside the country, becoming paradigms to follow in the matter, and continuous sources of income, without damaging the pockets of society and promoting the State in parallel, as a highly competitive company and capturing the best workforce in the country, with high and permanent salaries.

Keywords: biodiversity conservation, ecological economics, ecosystem services, state ecosystem system, industrial ecology, bioeconomics.

\section{JEL Classification: Q570.}

Cite as: Castro, Ed. F. A. O. (2019). Taiwan: Reference Of Good Practices For Latin America In Clean Industry SocioEconomic Challenges, 3(2), 110-126.https://doi.org/10.21272/sec.3(2).110-125.2019.

(C) The Author, 2019. This article is published with open access at Sumy State University.

\section{Introduction}

The annual report of the World Wildlife Fund (1961, WWF), with the Living Planet Report 2016, marks a trend of what is happening on the planet, in front of all living things. In a term of more than four decades, 1970-2012, fish in water, disappeared almost completely, at a level of $81 \%$, i.e. average, during these years decreased to about an annual rate of 3.9\%. Since the beginning of the 1970s, vertebrates, in their natural habitats of savannas, forests and deserts, disappeared by $38 \%$, at an annual average of $1.1 \%$ per annum, and in the event of a catastrophe, report points out that in more than four decades, about $58 \%$ of the vertebrates of planet earth, "mammals, birds and fish (World Wildlife Fund WWF, 2016). 
There is data, to show how devastating this change has been: despite the fact that last century, the average sea level increased about 17 centimeters, this last decade of the millennium, it shows what happened, since the level has already grown close to double what happened last century, showing the "rapacity" of the water from the sea and the speed with which this episode is generating, evidencing a clear environmental imbalance (White, 2006).

In the same way, it uses through the Appendix, the explorer more about as the city concept.

In the second part, "Takeoff, institutionalization and moral bases of environmental policy", shows in principle the moral support of this "green road", from Confucianism and then from Neo-Confucianism, the cornerstone of the social walk of the Island. On the other hand, it shows the conformation of the first institutions that still belong to the Second World War, as a State, they understood the need to place this "green" policy in the category of the great vertices of the modern state, leaving this subject under the planning and execution of the Executive Yuan and the Department of Health. He was giving life to this issue, as a particular public policy and driven by the high Government, which planned, integrated with other policies, such as education, health, roads.

In the in the third part of the document, "Taiwan, environmental paradigm to reference", the center seeks to answer:

\section{Why Taiwan is an environmental paradigm, with emphasis on the theme of "Clean Industry"?}

As will be shown the structure achieved today, it is integral to other environmental processes, ranging from working with air, to garbage collection, through the back office of companies. Until a couple of decades ago, in several parts of the country, the level of pollution was double, that accepted by then, in U.S., and many of its waters, were contaminated with industrial chemical wastes. Thanks to its creative, investigative capacity, state management and social conscience, today the country is considered as a world leader in the environmental theme, recognition, which among others, is given in this second decade of the millennium, by the US Environmental Protection Administration. (TAIWAN REPUBLIC OF CHINA: Taipei Economic and Cultural Representative Office, 2015)

In other cases, of garbage in its cycle of collection and citizen participation, I went several times to observe the same, in cities such as Taipeï, Zhongly, Taoyuan, in the Campus of the "National Central University", in the course, of 2016.

In the case of state enterprises and agencies, I visited Mr. Ray Reu, of the Industrial Technology Research Institute ITRI, Office of Environment \& Safety Technology Division- Green Energy and Environment Research Laboratories. Two decades in ITRI, of this expert and recognized Taiwanese, working with the theme associated with the environment, served as a testimony, not only to contextualize the evolution of the "green public policy" of the Island, but, to know the processes recommended by ITRI, for specific cases, in the field of Clean Industry and complementary microprocessors.

The document, has a contribution made in the field of formative research, by the student, Mateo Andrés Rodríguez Morales, belonging to the group "Elite" of the Business Administration Programme of the University Piloto of Colombia, led by the Professor Oscar Gómez, of the same Programme. In recognition of their academic efforts in the first two years of the study, students will be rewarded among others, participating in research processes, which will contribute in their training in this task. His contribution, focused on the development of APPENDIX A.

The conclusions of this work, rather than being a strict reference to the Taiwanese model, seeks to create a point of reflection on the environmental issue, in the heads of the leaders, presidents, leaders of Latin America, to find alternatives and solutions, which not only include short ages, but think of ceasing to focus exclusively on taxes as a way to structures value chains, full of innovation and about the good treatment of the environment.

The main objective of the study is to publicize the pillars of Taiwanese environmental public policy and its singularities vis-à-vis the world. The problem that seeks to work on this document, focuses on the environmental issue, the problem addressed, is in to know, which to discover the basic parameters that a country must have, to implement an environmental and effective public policy. 
SocioEconomic Challenges, Volume 3, Issue 2, 2019

Each one of the sections of this document in its historical walk, since 1895, when the Japanese Empire took the Island of Taiwan, seek to give a reference of each step that the Taiwanese State, gave in this sense.

Hand in hand and the commitment of its people, they manage to build "an environmental roadmap", determine management indicators and establish a "green national" culture, achieving to become a global paradigm to date.

\section{Conferences and agreements of the XX and XXI century}

The environmental issue has had an important deployment, discussion, compilation, updating of information, projection of the topic, at the head of the United Nations part of the International Agenda, from the 1970s, becoming definitive and incorporated as one of the seven Millennium Development Goals (MDGs) and then, as indivisible when acting against the "Climate Change" of the signatories of the "Paris Agreement" of 2015 until today. This way, in the International Agenda can be consulted in Table 1, "Agreements and conferences on the environmental issue".

United Nations Conference on Environment \& Development, from 3 to 14 June 1992. It was known as the "Earth Summit" or "Rio Summit". For many specialists, from here came the long-term road map, on the subject. It was attended by 108 Presidents and achieved key documents: "Program 21"; way to continue in the world in the matter of sustainable development; "The Rio Declaration", establishing rights-obligations, of the States themselves towards sustainable development and the environment.

(Naciones Unidas, s.f.).

Special Session of the General Assembly-Plenary, for the Review and Evaluation of the Implementation of Agenda 21, from 23 to 27 June 1997. Topics touching on practical elements of what is expected, are the cities of the 21 st century and will then give concrete projects like those of "Clean Industry" within or in the rings of the cities (Naciones Unidas, s.f.). In Appendix A, some basic criteria and contributions of model cities is found.

Kyoto Protocol, 11 December 1997. Its basic objective is to achieve a fall in the emission of six greenhouse gases (GHG): sulfur hexafluoride (SF6), carbon dioxide (CO2), nitrous oxide (N2O), perfluorocarbons (PFC), methane gas ( $\mathrm{CH} 4)$, Hydrofluorocarbons (HFCs); cause of global warming.

Commitment, reduce these emissions by at least 5\%. The application and entry into force has been late in the largest generators of these gases. Russia signed the Protocol until 2004. (UNFCC, s.f.). United States in 2015 (BBC MUNDO, 2015), a goal of reduction of close to $30 \%$ of the same, by 2030 (MUNDIALES, INSTITUTO DE RECURSOS, s.f.).

Millennium Development Goals. Sustainability (Protecting our common environment /22-23), of the environment was included as one of the so-called Seven Millennium Development Goals (MDGs) by the United Nations (Nacioneds Unidas, s.f.).

World Summit on Sustainable Development (WSSD), 26 August to 4 September 2002. It is sought that the "Agenda 21" that establishes the way forward since 1992 on Sustainable Development, has concrete processes, on the part of the signatory States to demand quantifiable achievements, at a given time period (Naciones Unidas, s.f.).

The United Nations Climate Change Conference, from 30 November to 12 December 2015.

Developed within the framework of the XXI Conference on Climate Change (COP 21). Called as the "Conference on Climate Change 2015". We work to face worldwide goal, to minimize the effects of

"Climate Change", (Naciones Unidas, s.f.). 
Table 1. Agreements and Conferences on the Environmental theme

\begin{tabular}{|c|c|c|c|c|}
\hline Agreement/ Conference & Year-Month & Day(s) & City/Country & General Purpose \\
\hline $\begin{array}{l}\text { UN Conference on the Human } \\
\text { Environment or Stockholm Con- } \\
\text { ference }\end{array}$ & 1972-June & 5 to 16 & $\begin{array}{l}\text { Stockholm/ } \\
\text { Denmark }\end{array}$ & $\begin{array}{l}\text { Declaration from the United Nations, on the preservation of } \\
\text { the environment, impact of heavy industry and technological } \\
\text { development. }\end{array}$ \\
\hline $\begin{array}{l}\text { World Comission on Environ- } \\
\text { ment \& Development (WCED) }\end{array}$ & 1987-April & 27 & London/ UK & $\begin{array}{l}\text { The term "Sustainable Development" is introduced. From } \\
\text { this results "Brundtland Commission, presents the "Brund- } \\
\text { tland Report". }\end{array}$ \\
\hline $\begin{array}{l}\text { United Nations Conference on } \\
\text { Environment \& Development }\end{array}$ & 1992-June & 3 to 14 & $\begin{array}{l}\text { Rio de Janeiro/ } \\
\text { Brasil }\end{array}$ & $\begin{array}{l}\text { Achieved key document: "Program 21"; way to continue in } \\
\text { the world in the matter of sustainable development; born } \\
\text { "The Rio Declaration", establishing rights-obligations. }\end{array}$ \\
\hline $\begin{array}{l}\text { Special Session of the General } \\
\text { Assembly for the Review and } \\
\text { Evaluation of the Implementa- } \\
\text { tion of Agenda } 21\end{array}$ & 1997-June & 23 to 27 & $\begin{array}{l}\text { NY/ United } \\
\text { States }\end{array}$ & $\begin{array}{l}\text { How cities will be in the } 21 \text { st century and will then give con- } \\
\text { crete projects like those of "Clean Industry". }\end{array}$ \\
\hline Kyoto Protocol & $\begin{array}{c}1997- \\
\text { December }\end{array}$ & 11 & Kyoto/ Japan & $\begin{array}{l}\text { Its basic objective is to achieve a fall in the emission of six } \\
\text { greenhouse gases (GHG): sulfur hexafluoride (SF6), carbon } \\
\text { dioxide (CO2), nitrous oxide (N2O), perfluorocarbons } \\
\text { (PFC), methane gas (CH4), Hydrofluorocarbons (HFCs). }\end{array}$ \\
\hline $\begin{array}{l}\text { Session of the General Assem- } \\
\text { bly/ Millennium Development } \\
\text { Goals }\end{array}$ & $\begin{array}{l}2000- \\
\text { September }\end{array}$ & 18 & $\begin{array}{l}\text { NY/ United } \\
\text { States }\end{array}$ & $\begin{array}{l}\text { Sustainability was included as one of the so-called Seven } \\
\text { Millennium Development Goals (MDGs). }\end{array}$ \\
\hline $\begin{array}{l}\text { World Summit on Sustainable } \\
\text { Development (WSSD) }\end{array}$ & $\begin{array}{l}\text { 2002- August } \\
\text { and } \\
\text { September }\end{array}$ & 26 to 04 & $\begin{array}{l}\text { Johannesburg / } \\
\text { South Africa }\end{array}$ & $\begin{array}{l}\text { Establishes the way forward since } 1992 \text { on Sustainable De- } \\
\text { velopment. Figures are analyzed that show the use of re- } \\
\text { sources and responsibilities with respect to their consump- } \\
\text { tion in the world }\end{array}$ \\
\hline $\begin{array}{l}\text { The United Nations Climate } \\
\text { Change Conference }\end{array}$ & $\begin{array}{l}2015- \\
\text { November } \\
\text { and } \\
\text { December }\end{array}$ & 30 to 12 & Paris/ France & $\begin{array}{l}\text { We work to face worldwide, to minimize the effects of "Cli- } \\
\text { mate Change". }\end{array}$ \\
\hline $\begin{array}{l}2016 \text { United Nations Climate } \\
\text { Change Conference }\end{array}$ & $\begin{array}{l}2016- \\
\text { November }\end{array}$ & 7 to 18 & $\begin{array}{l}\text { Marrakech } \\
\text { /Morocco }\end{array}$ & $\begin{array}{l}\text { We worked on the planning and compliance with the terms } \\
\text { of the Paris Agreement (recognized by the acronym-CMA1), } \\
\text { associated with "Climate Change". }\end{array}$ \\
\hline $\begin{array}{l}2017 \text { United Nations Climate } \\
\text { Change Conference }\end{array}$ & $\begin{array}{l}2017- \\
\text { November }\end{array}$ & 6 to 17 & $\begin{array}{l}\text { Bonn/ } \\
\text { Germany }\end{array}$ & $\begin{array}{l}\text { The Agreement, by its acronym (COP23), determines the } \\
\text { "step by step" for the implementation of the "Paris Agree- } \\
\text { ment", establishing the so-called "Talanoa Dialogue", which } \\
\text { will be the support for the countries that in this process es- } \\
\text { tablished since the Meeting de Paris (2015), serves to help } \\
\text { those countries, which seek implementation and start-up, by } \\
\text { the year } 2020 \text {. }\end{array}$ \\
\hline $\begin{array}{l}2018 \text { United Nations Climate } \\
\text { Change Conference or, Katowice } \\
\text { Climate Change Conference }\end{array}$ & $\begin{array}{c}2018- \\
\text { December }\end{array}$ & 2 to 15 & $\begin{array}{l}\text { Katowice/ } \\
\text { Poland }\end{array}$ & $\begin{array}{l}\text { It determines the tools that allow the measurement and es- } \\
\text { tablishment of achievements or progress in them, according } \\
\text { to the objectives accepted in the "Paris Agreement" of } 2015 .\end{array}$ \\
\hline
\end{tabular}

Source: the author, based on data obtained from the agreements, conferences and documents, issued and related in this document.

\section{Takeoff, institutionalization and moral bases of environmental policy}

In this second part, describes the basis of the beginning of this "green path", which starts from a key principle of this culture: to have a moral support in its actions of social impact, taking Confusionism as a starting point and reference that will allow a clear horizon and precise in the matter. See the Table 2, "Timeline, public policy and environmental example".

\section{Confucianism Respect and Love of Nature}

China, from about $500 \mathrm{BC}$, and in 1949, it had two major sources, on the issue related to the deterioration of the environment: the search to become a state of high military power and therefore political in the area (500 $\mathrm{BC}-1,000 \mathrm{AD})$; the exponential increase of its population with its uncontrolled pressure on resources, period 1000-1949 (Mark, 1993).

Entering into the conception of the Taiwanese people today, in the face of their relationship with the environment, is in the framework of the Chinese people's thought tradition, which for centuries has in its great thinker Confucius (551 BC-479 BC), the base to many responses as a society and as a nation. Under the concept of Humanist Confucianism, a division between Nature and the Human is never accepted, always interacting in harmony (Huang, 2009). 
SocioEconomic Challenges, Volume 3, Issue 2, 2019

\section{Neo-Confucianism}

On the other hand, from the eleventh century, retakes these ideas, from its vision of the cosmos, in the relation, between the man and the nature, that surrounds it (Columbia University, 1988). One of its founders, the philosopher Zhang Zai (1020-1077), Commented "heaven is my father and the earth my mother and even a being as small as I find an intimate place between them" (Yao, 2001).

\section{Religious syncretism}

Although there is a "religious syncretism" in Taiwan, which combines traditions of its early settlers, with Taoists and Buddhists, the importance of Confucianism is as evident as real, appreciated by the great majority of its inhabitants. A proof of this, in the Island, until 2012, there were 13 official temples of Confucius, one of them is in Tainan, that rose in the year of 1655, during the last Dynasty, the Qing (1644-1912). It is chosen by all its leaders, from the time it was created, which includes eight emperors and all the Presidents, after the end of the Second War, to place a "Spiritual Tablets" on its ceiling, with a verse of four Chinese characters. Where the leaders express, under the Confucian vision, the political approach that characterizes it. This, before the Taiwanese people, not only legitimizes them, but also achieve the acceptance of their nation from the depths of their heart (TAIWAN TODAY, 2012).

\section{Early Institution, on the Environmental theme, from the Constitution of 1947}

When the Taiwanese state took off in 1947, the new constitution came into effect; in addition services associated with health care and prevention activities, explicitly includes the promotion of "environmental sanitation", and is beginning with the Department of Health. The strategy continues with the Second Four-Year Plan (1957-1960), in the sixties, when the Island built five Industrial Parks. There was no location and comprehensive spatial strategy, which would locate the first large factories, seeking thereby to minimize the impact on pollution (Bustelo, 1994).

Topics, water, garbage in your collection cycle, air condition and noise impact. This environmental take-off is not alien to a reality, the agrarian condition of the island, which left the export path as the basis of the model, a fact learned during the period of Japanese colonialism (1898-1947). In 1950, about $90 \%$ of its exports came from the primary sector; more a decade later 1960-1964, its participation was around 60\% (U.S. Congress, 1995).

Understanding the importance of water, the Ministries of Economic Affairs MOEA (1931), established as a specialized office, the Water Resource Integrated Planning Commission (Environmental Protection Administration Executive Yuan R.O.C., s.f.).

The Executive Yuan, "Environmental Health Division", the Department of Health, established the "Office of Environmental Protection", which since 1979 was responsible for environmental health and pollution impact, which came from that exponential business-industrial growth, the environment is such that this industrial expansion led the country to average growth levels of 7.5\% in the years 1981-1985 (Kuo, 2015).

In 1983, thinking of concentrating water problems, their toxicity and waste treatment, these tasks were handed over to the "Office of Environmental Protection"; A year later all cities, assigned to a Health Office, to receive and manage urban cases associated with the environment (Environmental Protection Administration Executive Yuan R.O.C., s.f.).

In 1987, the Department of Health, the Executive Yuan, and the Environmental Protection Office launched the "Environmental Protection Administration" or EPA, which is responsible for public environmental policy, the standardization of processes, monitoring and inspection and the derived regulations. This led to the creation in October of that year of the First Comprehensive Plan for Public Policy: the "Guidelines for Environmental Policy at the Current Stage" (Ho, 2013).

In order to centralize and return effective, it is assigned seven specialized departments: Sanitation and handling of toxic substances, integral planning, environmental monitoring, air quality protection and noise 
control, monitoring and evaluation of dispute resolution, protection of Quality of water and the key to an objective public policy, its Information Center. See the Table 2, "Timeline, public policy and environmental example".

To create decentralized agencies, which from the big capitals, develop local plans and programs, integrated with national objectives. In this regard, it is important to appoint the Administration of the great port of Kaohsiung, which delegates concrete actions to its departments. The Department of "Cleaning Management", integrated the tasks of collection and management of garbage and water drainage, creating comprehensive programs, in the late seventies was its Environmental Department who integrated these tasks. For its part, the capital, establishes the "Water Pollution Control Institute", which deals with wastewater and even, the own investigation on the subject (Ho, 2013).

Thanks to these developments, between 1988 and 1991, a year before the United Nations Conference on Environment \& Development, from 3 to 14 June 1992, the country was able to form Offices in major cities, specialized in the themes local and integrated with national policies that protect the environment (Environmental Protection Administration Executive Yuan R.O.C., s.f.).

\section{Taiwan, Environmental Paradigm to Reference}

The analysis seeks the basis for why Taiwan has been a global reference in Clean Industry for Asia since before the United Nations Conference on Environment \& Development (1992) for America Latin and much of the world today.

At the end of the eighties, there is already a legal norm, clear against the chain of recycling, which towards the nineties determines the creation of the "Recycling Fund Management Board"; since the beginning of the nineties, categorize products according to their environmental impact with their "Green Mark Program", even those from entrepreneurship projects and since the middle of the decade, strict rules have been established against pollution generated from the factories that looked for zones of "zero pollution"; in the millennium there is a traceability to processes that generate advances in the face of environmental impact, from the company to the academy, the health sector, even from the State itself, and its companies; At the end of the second decade, it is included in the "Clean Industry" value chain, to the stores, which due to their coverage (first in the world) and social impact, are decisive in this purpose, recognizing them for their achievements through the program "Green Store", of which brands of final goods and suppliers are part; beginning the second decade of the millennium, its zones of "zero external pollution", became a purpose within the companies and their factories; its institution of commercial promotion in the world TAITRA, launches the "Taiwan International Green Industry Show".

This Island, is decisively determined to be a global paradigm in clean sources of clean energy, which feed your company, today with $70 \%$ of the production of electronic circuits in the world and about $80 \%$ of semiconductors, for this between 1995 and 2015, in these twenty years, it became the second producer of solar panels after the People's Republic of China, all over the world, which will take it to the year 2015, to replace its nuclear energy with clean energy (Mathews, 2016).

For the millennium, the State seeks to prioritize socialization and environmental awareness. In 2002, the EPA Government announced 43 categories from which to lead the work, in areas such as academic (colleges, universities), companies and hospitals, owned by the State. The process was integral, it was decided that the purchases of its inputs, be of those with the label "Green Mark" (Public Construction Commission Executive Yuan, s.f.).

For 2007, the EPA includes its "Green Stores" program, which demonstrates "Green Store Best Practices", which includes marketing its products, thereby seeking to include "local retailers" in retail chains with the support of the local Environmental Protection Offices. In 2009, included the Back Office of the processes, seeking that the value chain, ensure the use of "Clean Technology", which discarded the processes "in situ", already audited. See the Table 2, "Timeline, public policy and environmental example".

Air pollution following the Air Pollution Control Act (APCA), in 1995, promulgated the "Air Pollution Control" (APC), and sought, pollution control from, cars, factories and constructions. However, the idea was more ambitious and aimed to create zero-pollution spaces, areas known as "Clean Air Zones". This idea takes off in the second part of the nineties, becoming a reality during the 
millennium, planting trees in particular spaces, thus generating green and sustainable solutions (Public Construction Commission Executive Yuan, s.f.).

As a world example, at the beginning of the second decade of the millennium, we opt for a higher objective: zero indoor pollution or Indoor Air Quality (IAQ). To do this in 2011, it enacted the "Indoor Air Quality Management Act" with the support of EPA (Environmental Protection Administration Executive Yuan R.O.C., 2012).

\section{Technology and Citizen Culture, basis of Credibility and Reliability.}

Entrepreneurs or involved in the processes like "Green Mark", local and national programs, have pages of the State, where they are inscribed in the same ones at specific level. In these pages, advances, quantitative targets against achievements, purchases of inputs with "Clean Technology" are pointed out, (Green Loiving, s.f.).

With the aim of promoting the best advances in Clean Industry, in 2009 the "Taiwan International Green Industry Show" (TIGIS) is launched. The same is done with the support of Taiwan External Trade Development Council (TAITRA), arm and support in relation to promotion, national-international Networking structure, specialized training, and pursuit of greater competitiveness, Taiwanese business structure, inside and outside the country (Show, s.f.).

The Waste Disposal Act (WDA) has been, since its creation in 1974, the standard that established the rules of the game on the subject of the recycling cycle. In addition, with a significant contribution, it typified the different types of waste, which allowed them to recognize and regulate each one. See the Table 2, "Timeline, public policy and environmental example". The existence of two large groups was determined: "Industrials" are general, random, those that are forbidden to "import", and those that will be part of an additional process of transformation. The second group, are the "Generals", known as General-incinerated, and by this additional process that consists of burning them in special public "chimneys", they are prohibited for their mobilization, (EPA, 2012).

To obtain their own budget, importers and companies were asked for a "Recycling Fee", their specific destination, to oxygenate a "Recycling Fund" that will contribute to the processes derived from recycling and for those Firms, who obtain their license to carry out these tasks, according to the national standard and the tutoring of EPA Taiwan Agency. Without neglecting this cultural change, a slogan was applied, worked in every public place, from schools, public and private offices, as a social educational contribution: "reduce, reuse (circular economy), recycle."

In 2005, a program was launched against collection, it was called "Separation at Source Legislation". With two phases, it managed to regulate the separation of recyclable waste, food and waste from food, included specifying the freedom for cities to set spaces to recycle and sell them (Allen, s.f.).

From then on, the whole society was involved: in the two years to be followed the use of disposable plates and glasses in State Colleges and Agencies was prohibited; it was sought to regulate the packaging of food, cosmetics, CDs, alcoholic beverages. Since 2007, a plan was signed with supermarkets to reduce the use of plastic bags gradually to 2011 , starting with $15 \%$ and reaching $35 \%$; in 2009 EPAT was able to sign an agreement with the five largest PC-producing companies so that in 2009 they would eliminate 3,700 tons of computer waste (TEPA, 2010). It was sought in 2008, very within the national culture, that both, convenience markets and coffee shops, will deliver "Chopsticks" disposable and in a single opportunity, achieving in 2008, reduce 350 tons in waste from this Taiwanese and Chinese cultural tool (TEPA, 2010).

Beginning in the second decade of the millennium, the government regulation compares and recycles purchased electronic material, where marketers, after the finished product life cycle, undertake to return to the final recycling cycle of this material. See the Table 2, "Timeline, public policy and environmental example". The boilers or incinerators of the same and under state permission, there were 24 in the country to the 2010: $40 \%$ of the material burned was destined to industrial waste and the rest, municipal waste of solid material (Allen, s.f.).

The basic phase of collection today, has its garbage collectors, arriving at pre-established corners, where they carry a team of trucks (two); locating them in time and space, can be done through "apps", mobile-readable. The back truck for paper (newspaper and magazines, white), the color horn, warning the arrival at the collection point, people carry their bags, certified by the government: red (food waste), blue (vegetable waste ), 
commit registered infractions, have fines from USD \$ 184, representative, understanding that it has been, close to something less than a third of a monthly minimum wage. This "Networking-social", has led in 2015, at recycling rates, 55\%, only comparable worldwide, with its neighbor South Korea and traditional in this sense, Germany and Austria (Chen, 2016).

The country became, in the second decade of the millennium, one with the lowest rates of waste generated per day, for each person: to create 1.14 kilograms per person in 1997, was changed to 2014, to 0.38 kilograms, that is to say a reduction of $300 \%$ (Executive Yuan Public of China (Taiwan), s.f.).

\section{International Cooperation and Certification, Formation of Interdisciplinary Teams.}

The EPA signed an agreement with the American Institute in Taiwan (AIT) for the year 1993. Since then the AIT has replicated and continuously demonstrated its decades-long experience in Africa, Asia and the Pacific And Latin America, establishing with it, a basis of "good practices" (EPA US, s.f.).

In another front of the subject, Taiwan decides to adopt since 2001, the norms of "Energy Star Labe". Applied since 1992 in the U.S., they seek to reduce the energy consumption of tools, such as PCs, servers, lights, household appliances, imaging equipment (photocopies), construction, refrigeration and heating (EnergyStar, s.f.).

In the use of photovoltaic (PV) energy, today it is based on mega projects, in countries like the United States, continents, as in Africa, Europe, and Asia, where they look for as in Taiwan surfaces that do not affect the balance Environmental, recommending for example spaces to the borders of the railroads or that are not suitable for crops. Since its business unit (AblyTek Co. Ltd., KY Solar, Botian, Ltd., LIGITEK, Speedtech Energy, Tynsolar, etc.), it has used its large companies, which are considered as the largest manufacturers of contract chips, DRAMs, Semi-conductors, in the world, thus have generated a robust industrial sector (Crook, 2016).

\section{Converted its energy needs, in options of technologies of low consumption and very low environmental impact.}

Another source of pollution, from the industry, transportation and housing in general, are the fossil, energy sources. With the impetus of the "Renewable Energy Development Act" of July 2009, the State has from this law, the Ministry of Economic Affairs (MOEA) and its Bureau of Energy (BOE), which supports the technical part, installation, dictates (by 2015, only $2.3 \%$ are left out), and implementation of photovoltaic (PV) energy.

The results are remarkable to October of 2015, it was passed in 2009 to produce $9.5 \mathrm{~mW}$ to $728.5 \mathrm{~mW}$, that is to say an exponential growth of 76 times the capacity, in 6 years, between the year 2007-2011, went from the fifth position, to second largest producer of solar panels, to date, is only surpassed by Taiwan. Business modalities, to facilitate the implementation of this technology, have many options. One of them, is that the owner of the property, does not need any money for the installation, the company guarantees you between $6 \%$ $-8 \%$, of income that comes from the sale of that energy created and sold to "Taipower," Signature of the State created in 1946, in charge of generating energy for the country. See the Table 2, "Timeline, public policy and environmental example". The agreement will have a 20 -year maturity, regardless of future owners, because in Taiwan, the term is contemplated in agreements between private bidders and the State Energy Firm (Crook, 2016).

The "Photovoltaic (PV) Industry", to 2015, has four segments: 59.1\% from the subsector, produces silicon cells; $22.7 \%$, Wafer production; $12.5 \%$, of photovoltaic material and $5.1 \%$, with the production of silicon modules. It has achieved in this sense a whole chain of value from Firms that produce pieces of microelectronics, to Firms that produce, design, innovate, and look for markets, against the PV. On the other hand, it has managed to channel two markets, India and Taiwan, as its largest demanders (National Develpoment Council, 2106).

Another source that favors the Industry and applicants in general, is the Wind or "Wind Power" field. The "Renewable Energy Development Act" seeks to substitute in the two decades to follow the dependence of nuclear energy and import, fossil fuels, led by gasoline. In 2014, it was possible to reach about 354,000 homes with this clean energy source, achieving a reduction of 776,000 CO2 emissions that year, (Executive Yuan Public of China (Taiwan), s.f.). 


\section{Purposes Through Public-Private Initiatives of International Scope.}

There is always the idea and public management, in terms of seeking international alliances. They seek, consolidate innovative products of Taiwanese companies and / or, transfer of technology in two ways, and generate income to companies, universities of the Taiwanese State, to replace those generated through their current income: taxes.

The company with the highest sales in the world of motorcycles, the Japanese Yamaha, will begin a strategic alliance with the Taiwanese company Gogoro, which manufactures electric motorcycles since 2011. This business synergy will allow Keiretsu Yamaha to design the new versions, and Gogoro, make them for the island. See the Table 2, "Timeline, public policy and environmental example".

This Taiwanese company, has a disruptive innovation, which gives a representative comparative advantage, its batteries are rechargeable in more than 750 points distributed throughout the island, with the alliance will reach about 1,000 points. The owner of the motorcycle, stops at the respective point, lifts the seat and from there takes out the discharged battery, places it in a "panel" of charge and changes it to another one that is inside this same panel, which is already loaded (NOTICIAS DE TAIWAN, 2018).

However, once again, the government is an integral part of this strategy that seeks to replace all motorcycles that use gasoline.

Public policy, part of this line from. The Industrial Development Bureau (IDB), promoted by the Ministry of Economic Affairs (MOEA), they have established aid to companies that, apart from Gogoro, produce this type of motorcycle and have worked on advertising so that each time they buy this type of vehicle, which minimizes the environmental impact. The amount of aid given to this type of company has grown nearly $250 \%$, in what is going through the year 2018, compared with these same aids given to the company in 2017, which explains why this year, the number of license plates for this type of motorcycles on the Island is already doubling. Companies like, Sanyang Motor Co. (SYM), China Motor Corp., Kwang Yang Motor Co. (KYMCO), already have several lines of motorcycles under this same technological scheme (NOTICIAS DE TAIWAN, 2018).

Table 2. Timeline, public policy and environmental example

\begin{tabular}{|c|c|c|c|c|c|}
\hline $\begin{array}{l}\text { Agreement/Conference } \\
\text { in the World }\end{array}$ & $\begin{array}{l}\text { Year- } \\
\text { Month }\end{array}$ & $\begin{array}{l}\text { Taiwán } \\
\text { Insitution } \\
\text { /Company }\end{array}$ & $\begin{array}{l}\text { Year(s)/ } \\
\text { Environ. } \\
\text { achiev. }\end{array}$ & \multicolumn{2}{|l|}{ Historical Phase } \\
\hline & & & $\begin{array}{l}500 \mathrm{BC}- \\
\text { today. }\end{array}$ & $\begin{array}{l}\text { Confusionism (500 BC), and Neoconfucionism }(1000 \\
\text { aprox), now Religiuos Syncretism, determine the moral } \\
\text { principles against the Environment. }\end{array}$ & Past. \\
\hline \multirow{4}{*}{$\begin{array}{l}\text { UN Conference on the } \\
\text { Human Environment or } \\
\text { Stockholm Conference }\end{array}$} & \multirow{4}{*}{ 1972-June } & \multirow{4}{*}{$\begin{array}{l}\text { Executive } \\
\text { Yuan and } \\
\text { the De- } \\
\text { partment } \\
\text { of Health }\end{array}$} & 1947 & $\begin{array}{l}\text { The new Constitution, included "environmental sanita- } \\
\text { tion". }\end{array}$ & \multirow{4}{*}{$\begin{array}{l}\text { Early Institution, } \\
\text { on the Environ- } \\
\text { mental theme, } \\
\text { from the Constitu- } \\
\text { tion of } 1947\end{array}$} \\
\hline & & & $1957-1960$ & $\begin{array}{l}\text { In the "Second Four-Year Plan", it seeks to minimize the } \\
\text { effect of pollution. }\end{array}$ & \\
\hline & & & 1971 & $\begin{array}{l}\text { Is moving towards a long-term solution, such as the im- } \\
\text { pact of pesticides, the use and management of wastewater, } \\
\text { regulation of "Food Processing Plants". }\end{array}$ & \\
\hline & & & 1974 & $\begin{array}{l}\text { Creation The Waste Disposal Act (WDA). Established the } \\
\text { rules of the game on the subject of the recycling cycle. } \\
\text { Typified the different types of waste, which allowed them } \\
\text { to recognize and regulate each one. }\end{array}$ & \\
\hline & & & 1976 & $\begin{array}{c}\text { The Ministries of Economic Affairs (MOEA), established } \\
\text { as a specialized office, Water Resource Integrated Plan- } \\
\text { ning Commission. }\end{array}$ & \\
\hline & & & 1979 & $\begin{array}{l}\text { Established the "Office of Environmental Protection", re- } \\
\text { sponsible for environmental health and pollution impact. }\end{array}$ & \\
\hline & & & 1983 & $\begin{array}{l}\text { Water problems, their toxicity and waste treatment, were } \\
\text { handed over to the "Office of Environmental Protection". }\end{array}$ & \\
\hline
\end{tabular}


Table 2 (cont.). Timeline, public policy and environmental example

\begin{tabular}{|c|c|c|c|c|c|}
\hline $\begin{array}{l}\text { Agreement/Conference } \\
\text { in the World }\end{array}$ & $\begin{array}{l}\text { Year- } \\
\text { Month }\end{array}$ & $\begin{array}{l}\text { Taiwán } \\
\text { Insitution } \\
\text { /Company }\end{array}$ & $\begin{array}{l}\text { Year(s)/ } \\
\text { Environ. } \\
\text { achiev. }\end{array}$ & \multicolumn{2}{|l|}{ Historical Phase } \\
\hline \multirow[t]{2}{*}{$\begin{array}{l}\text { World Comission on En- } \\
\text { vironment \& Develop- } \\
\text { ment (WCED) }\end{array}$} & \multirow[t]{2}{*}{$\begin{array}{l}\text { 1987- } \\
\text { April }\end{array}$} & & 1987 & $\begin{array}{l}\text { With "Office of Environmental Protection", launched the } \\
\text { "Environmental Protection Administration" (EPA). } \\
\text { Eesponsible for public environmental policy, the standard- } \\
\text { ization of processes, monitoring and inspection and the de- } \\
\text { rived regulations. To create decentralized agencies, which } \\
\text { from the big capitals, develop local plans and programs, } \\
\text { integrated with national objectives. }\end{array}$ & \\
\hline & & & 1988 & $\begin{array}{c}\text { Established in this sense that importers and manufacturing } \\
\text { companies had to form associations, aimed at managing } \\
\text { recycling. }\end{array}$ & \\
\hline \multirow{3}{*}{$\begin{array}{l}\text { United Nations Confer- } \\
\text { ence on Environment \& } \\
\text { Development }\end{array}$} & \multirow{3}{*}{ 1992-June } & \multirow{3}{*}{ EPA } & 1992 & $\begin{array}{l}\text { Established by the State, the "Green Mark Program". Es- } \\
\text { tablishes } 112 \text { categories of products, where they go near } \\
6,000 \text { tangibles. }\end{array}$ & \multirow{6}{*}{$\begin{array}{l}\text { Taiwan, } \\
\text { environmental } \\
\text { paradigm to } \\
\text { reference. }\end{array}$} \\
\hline & & & 1993 & $\begin{array}{l}\text { EPA signed an agreement with the American Institute in } \\
\text { Taiwan (AIT). AIT has replicated and continuously } \\
\text { demonstrated its decades-long experience in Africa, Asia } \\
\text { and the Pacific And Latin America, establishing with it, a } \\
\text { basis of "good practices". }\end{array}$ & \\
\hline & & & 1995 & $\begin{array}{l}\text { Promulgated the "Air Pollution Control" (APC), and } \\
\text { sought, pollution control from, cars, factories and con- } \\
\text { structions. Aimed to create zero-pollution spaces, areas } \\
\text { known as "Clean Air Zones". }\end{array}$ & \\
\hline \multirow[b]{2}{*}{$\begin{array}{l}\text { Special Session of the } \\
\text { General Assembly for } \\
\text { the Review and Evalua- } \\
\text { tion of the Implementa- } \\
\text { tion of Agenda } 21\end{array}$} & \multirow[b]{2}{*}{ 1997-June } & \multirow[b]{2}{*}{ EPAT } & 1997 & $\begin{array}{l}\text { How cities will be in the } 21 \text { st century and will then give } \\
\text { concrete projects like those of "Clean Industry". }\end{array}$ & \\
\hline & & & 1997 & $\begin{array}{l}\text { "Recycling Program", this formalizes the recycling opera- } \\
\text { tion, seeks to generate its own resources, to make the ac- } \\
\text { tion sustainable, without being an additional tax burden. It } \\
\text { is now the EPAT Agency, which creates the "Recycling } \\
\text { Fund Management Board" (RFMB), its role, to administer } \\
\text { the "Recycling Funds". } \\
\text {. }\end{array}$ & \\
\hline Kyoto Protocol & $\begin{array}{c}\text { 1997- } \\
\text { December }\end{array}$ & & & & \\
\hline \multirow{2}{*}{$\begin{array}{l}\text { Session of the General } \\
\text { Assembly/ Millennium } \\
\text { Development Goals }\end{array}$} & \multirow{2}{*}{$\begin{array}{l}2000- \\
\text { September }\end{array}$} & \multirow[t]{2}{*}{ EPA } & & & \multirow{5}{*}{$\begin{array}{l}\text { The millennium, } \\
\text { Taiwan as an ex- } \\
\text { ample for the } \\
\text { World. }\end{array}$} \\
\hline & & & 2001 & $\begin{array}{l}\text { To adopt, the norms of "Energy Star Labe". Applied since } \\
1992 \text { in the U.S., they seek to reduce the energy consump- } \\
\text { tion of tools, such as PCs, servers, lights, household appli- } \\
\text { ances, imaging equipment (photocopies), construction, re- } \\
\text { frigeration and heating. }\end{array}$ & \\
\hline \multirow{3}{*}{$\begin{array}{l}\text { World Summit on Sus- } \\
\text { tainable Development } \\
\text { (WSSD) }\end{array}$} & \multirow{2}{*}{$\begin{array}{l}\text { 2002- } \\
\text { August } \\
\text { and } \\
\text { September }\end{array}$} & \multirow{2}{*}{$\begin{array}{l}\text { EPA- } \\
\text { TAITRA- } \\
\text { MOEA }\end{array}$} & 2005 & $\begin{array}{l}\text { "Separation at Source Legislation". With two phases, it } \\
\text { managed to regulate the separation of recyclable waste, } \\
\text { food and waste from food, included specifying the free- } \\
\text { dom for cities to set spaces to recycle and sell them. }\end{array}$ & \\
\hline & & & 2007 & $\begin{array}{l}\text { EPA includes its "Green Stores" program, which demon- } \\
\text { strates "Green Store Best Practices". Include "local retail- } \\
\text { ers" in retail chains with the support of the local Environ- } \\
\text { mental Protection Offices. A plan was signed with su- } \\
\text { permarkets, to reduce the use of plastic bags gradually, to } \\
2011 \text {. }\end{array}$ & \\
\hline & & & 2009 & $\begin{array}{l}\text { "Green Stores" program, included the Back Office of the } \\
\text { processes, seeking that the value chain, ensure the use of } \\
\text { "Clean Technology". With the support of Taiwan Ex- } \\
\text { ternal Trade Development Council (TAITRA), promoting } \\
\text { the best advances in Clean Industry, with the "Taiwan In- } \\
\text { ternational Green Industry Show" (TIGIS). "Re- } \\
\text { newable Energy Development Act". With Ministry of Eco- } \\
\text { nomic Affairs (MOEA) and its Bureau of Energy (BOE), } \\
\text { supports the technical part, installation, dictates (by 2015, } \\
\text { only 2.3\% are left out), and implementation of photovol- } \\
\text { taic (PV) energy. }\end{array}$ & \\
\hline
\end{tabular}


Table 2 (cont.). Timeline, public policy and environmental example

\begin{tabular}{|c|c|c|c|c|c|}
\hline $\begin{array}{l}\text { Agreement/Conference } \\
\text { in the World }\end{array}$ & $\begin{array}{l}\text { Year- } \\
\text { Month }\end{array}$ & $\begin{array}{l}\text { Taiwán } \\
\text { Insitution } \\
\text { /Company }\end{array}$ & $\begin{array}{l}\text { Year(s)/ } \\
\text { Environ. } \\
\text { achiev. }\end{array}$ & \multicolumn{2}{|l|}{ Historical Phase } \\
\hline & & & 2011 & $\begin{array}{l}\text { Enacted the "Indoor Air Quality Management Act" with } \\
\text { the support of EPA. Born "zero indoor pollution" or In- } \\
\text { door Air Quality (IAQ). In the second decade of the } \\
\text { millennium, one with the lowest rates of waste generated } \\
\text { per day, for each person: to create } 1.14 \text { kilograms per per- } \\
\text { son in 1997, was changed to } 2014 \text {, to } 0.38 \text { kilograms, that } \\
\text { is to say a reduction of 300\%, Taiwan an Example for thr } \\
\text { World. }\end{array}$ & \\
\hline \multirow{2}{*}{$\begin{array}{l}\text { The United Nations Cli- } \\
\text { mate Change Confer- } \\
\text { ence }\end{array}$} & \multirow{2}{*}{$\begin{array}{l}2015- \\
\text { November } \\
\text { and } \\
\text { December }\end{array}$} & $\begin{array}{l}\text { The In- } \\
\text { dustrial } \\
\text { Develop- } \\
\text { ment Bu- } \\
\text { reau } \\
\text { (IDB), }\end{array}$ & 2015 & $\begin{array}{l}\text { In } 2014 \text {, it was possible to reach about } 354,000 \text { homes } \\
\text { with this clean energy source, achieving a reduction of } \\
776,000 \mathrm{CO} 2 \text { emissions that year. Results for the imple- } \\
\text { mentation of photovoltaic (PV) energy. Passed in } 2009 \text { to } \\
\text { produce } 9.5 \mathrm{~mW} \text { to } 728.5 \mathrm{~mW} \text {, an exponential growth of } \\
76 \text { times the capacity, in } 6 \text { years, between the year } 2007- \\
\text { 2011, went from the fifth position, to second largest pro- } \\
\text { ducer of solar panels, to date, is only surpassed by the PR } \\
\text { China. }\end{array}$ & \multirow{2}{*}{$\begin{array}{l}\text { With results, an } \\
\text { environmental } \\
\text { paradigm to be } \\
\text { referenced Glocal }\end{array}$} \\
\hline & & $\begin{array}{l}\text { by the } \\
\text { Ministry } \\
\text { of Eco- } \\
\text { nomic Af- } \\
\text { fairs } \\
\text { (MOEA) }\end{array}$ & 2018 & $\begin{array}{l}\text { They have established aid to companies that, apart from } \\
\text { Gogoro, produce this type of motorcycle (with "Clean En- } \\
\text { ergy") and have worked on advertising so that each time } \\
\text { they buy this type of vehicle, which minimizes the envi- } \\
\text { ronmental impact. }\end{array}$ & \\
\hline
\end{tabular}

Source: the author, based on data obtained from the agreements, conferences and documents issued and related in this document.

\section{Conclusions}

To enumerate, trafficking in endangered species, illegal and massive hunting in some cases (the red macaw, toucan, jaguar, etc.), waste of water, accompanied in many parts by an old infrastructure of public services, from the great cities of Sao Paulo, Santiago, the Federal Capital of Mexico, the greenhouse effect, by excess of gases from $\mathrm{CO} 2$, in large cities, illegal mining, which has in Colombia and Brazil, transgenic crops in Brazil, Mexico and Argentina, deforestation in one of the lungs of the world, the Brazilian jungle (Agencia Latinoamericana de Información, 2015).

This action, often irresponsible, has helped to generate the so-called "Climate change", manifested by the rapid rise in temperature in the last decades and its consequent effect on the poles and the life of all nature. To adapt to this cruel reality, the effects are more and more disastrous, since the "glaciers", present at present a significant setback in the whole world. From the same Andes in South America, passing through the European Alps, the visited Rocky Mountains, the north-western United States, the Himalayas, the heart of Everest and Alaska, the damage in their levels before perpetual, is evident (Center, National Snow \& Ice Data, s.f.).

According to studies, the temperature has increased significantly since 1880 , with inflection points since then (Crudata, s.f.). For example, two decades of high temperatures have been detected since 1981. Today the alarms are kept on extreme temperatures, recognizing that a downward point was achieved, from the impact of solar effects, in the period 2007-2009 (Al., 2009).

Having a moral reference for this society, since Confusio, who understands and interprets the environment, as part of personal balance. In the case of Taiwan, has served to lead from the State itself, processes of this nature and believe in them, as part of the "personal balance" and social. We need leaders in Latin America who believe in these processes and who, beyond their political interests and personal image, manage to form interdisciplinary groups that guarantee the application and fulfillment of achievements and objectives, beyond the presidential periods, but as part of a moral commitment with their voters, and with the new generations, who deserve to have a habitat full of hope and alternatives of coexistence.

On the other hand, this policy is integrated into the quinquennial, quadrennial plans of the country, which since the early fifties has become the "roadmap" of the objectives and goals of each government, as of 1953. 
This procedure, in the second five-year Plan (1957-1960), has achieved that in the environmental issue, guarantee human and financial resources, allowing to achieve goals and objectives set, regardless of the new government of the day, nor its purely political interests, nor its ideologies.

The global situation, shows that we must have as a global objective the care of the environment, from the industrial, but as it was observed involving a culture of respect for the care of the same. This Taiwanese paradigm, makes us see, how respect and belonging to the environmental issue, should start with the education of children, of an integral type, that is, it must involve both minors, as well as their parents, who must be observers of achievements and guarantors, that is, that the classroom is the laboratory, where the rules aimed at rescuing are met, a "green conscience", with the tutoring and continuous counseling of its professors.

On the other hand, the Taiwanese paradigm, public policy, successful, is because, in large part, it is possible to involve the different levels of society, under one principle: good faith. The State should not become exclusively an "Environmental Police", but, who periodically reports and revises the achievements, the objectives. Successful green public policy, is clear transparent, non-discriminatory, has simple but strictly enforceable objectives and goals. Taiwan is a global example, with a great macroeconomic reference for Latin America and its Ministers of Finance: the only way to fund these processes is NOT raising taxes, which can ultimately damage the degree of ownership of these policies, the citizens will see it as punishment, retaliation to favor "other" political groups or, to continue to cover embezzlement for the misuse of resources.

Public policies in their application and management in Latin America, have an intrinsic problem. Its application implies an increase in national or regional taxes, even local taxes in cities. This phenomenon, because the studies and plans have been years with a "costing" at prices that at the time of putting it to march implies adjustments for accumulated inflation and "extension of the contract", new suppliers, close relationship of contractors with the new government party. However, the application of economic policy, associated with the management of environmental public policy, has a "new recipe" Taiwanese style, which does not imply an increase in taxes, but a financing for environmental services rendered.

It is a Taiwanese tradition, to have management references, searching the world for the best representatives of each practice. For example, at the end of the 1950s in 1958, Wall Street officials, supervised, to achieve the establishment of the Stock Exchange. In 1961, the "Measures for Administration of Securities Dealers" was issued, with this governmental support, as a result of this counseling, the operations on the stock exchange of its operators and customers are monitored.

To exemplify what was said, in the year of 2007, the "Green Stores" was established by State initiative, recognition extended in 2009, to that related in this sense from the same "Back Office". With this program, it is sought to highlight the "good practices" that in this area, these commercial units make in their retail sales points. These processes include from the same advertising campaigns, through its management "in situ" with your client, who not only motivate these practices, but also provide a healthy environment, not even in packaging, the product itself, recycling inside the store, generate or inset damage to the environment.

Seeks to turn this action into a pleasant and friendly activity with the participants. Normally, a small caravan of trucks arrives, two of them, which can be located, through an "App" that starts from giving the route, parking spaces, establishes schedules, of their arrivals, and collection offices, as process times. Like everything Taiwanese, with schedules fulfilled sacredly. In addition, one of these trucks, which has two operators, remembers his arrival accompanied by pleasant music and recognized with melodies, many of them national, which invites to place, people, their waste, in bags, which can be vegetables, meals, solids, in bags certified by the same Taiwanese State, in its quality and technical dimensions.

In a report last May, made by the World Health Organization, "taking as evidence what happened in recent years (2008-2016), in 4300 cities, from 108 countries, of the nearly seven million deaths, whose origin it is the pollution, around $60 \%$ of them, come from Asia, (Organization, 2018). It is evident the environmental damage and more in the air that is breathed in the whole world, but more in this Continent. For this reality, more than two decades ago, once anticipating any urgent action in the world, Taiwan in 1995, innovates as always in terms of effective public policy, establishes a standard of "Air Pollution Control", aiming for "zones of zero pollution" or "Clean Air Zones". Always, breaking the limits of quality and innovation in public management, at the beginning of the second decade of the millennium takes a step above the standards and 
levels of global demand: the establishment of "zones of zero pollution within constructions "or" Indoor Air Quality".

The Taiwanese, like the Japanese and in the last decade, the Koreans and the Chinese people, have always been clear about the need to "copy" good practices, but if they come from the best exponents in the world on the subject. So Deming, Joseph Juran, Alex Osben, contributed to create the Japanese Quality Model itself, later considered the best in the world, ten years after ending the Second World War, which took place in the Japanese Union of Scientists and Engineers (JUSE) from 1949 until today as its maximum organism.

From the view of Deng Xiao Ping, the highest Chinese leader who led China to become the "Factory of the World", at the end of the seventies, to the industrial plant of Toyota, in 1982, during the XII Congress National of the Chinese Communist Party in 1982, proposed the establishment of a Socialism with Chinese characteristics, a hybrid form between Socialism and the Market Economy, known as "Market Socialism". In the same way, the Taiwanese create the "Environmental Protection Administration Executive (EPA).

Finally, the countries of Latin America, bordering on the tropics of Cancer or Capricorn, have sun all year round; The only country that has no outlet to the sea is Bolivia; Almost all countries have coastlines; That is to say, cleaner technology, such as the use of wind energy, solar energy, more research on adapting or creating its own clean energy sources should be used, which will also fuel the company's energy consumption; Research and Development and new patents should be facilitated and motivated in the face of these.

\section{References}

1. Agencia Latinoamericana de Información. (17 de jul de 2015). Agencia Latinoamericana de Información. Recuperado el 20 de october de 2016, de http://www.alainet.org/es/articulo/171253

2. Al., A. e. (2009). The Copenhagen Diagnosis: Updating the Updating the World on the Latest Climate Science. Sidney, Australia: UNSW Climate Change Research Center.

3. Allen, C. (s.f.). No burn.org. Recuperado el 17 de november de 2016, de http://www.noburn.org/downloads/ZW\%20Taiwan.pdf

4. Bataller, A. (s.f.). Castellano es. Obtenido de http://www.castello.es/archivos/12/Foros_Urbanismo_p.pdf

5. BBC MUNDO. (4 de agosto de 2015). BBC MUNDO. Recuperado el 7 de diciembre de 2016, de http://www.bbc.com/mundo/noticias/2015/08/150803_eeuu_obama_plan_emisiones_carbono_ep

6. BBC MUNDO. (23 de february de 2016). Obtenido de http://www.bbc.com/mundo/noticias/2016/02/160223_viena_ciudadades_calidad_am

7. BERMUDO, M. (2001). Revista Electrónica de Geografía y Ciencias Sociales. (U. d. Barcelona, Ed.) Obtenido de http://www.ub.edu/geocrit/sn-94-32.ht

8. Bustelo, P. (1994). La industrialización en América Latina y Asia Oriental: un estudio comparado de Brasil y Taiwán. Madrid, España: Complutense.

9. Center, National Snow \& Ice Data. (s.f.). National Snow \& Ice Data Center. Recuperado el 2 de december de 2016, de http://crudata.uea.ac.uk/cru/data/temperature

10. Centro de Información de las Naciones Unidas CINU. (s.f.). Centro de Información de las Naciones Unidas CINU. Recuperado el 15 de 0ctober de 2016, de : http://www.cinu.mx/temas/medioambiente/medio-ambiente-y-desarrollo-so/

11. Chen, K. (17 de may de 2016). Wall Street Journal. Recuperado el 10 de october de 2016, de : http://www.wsj.com/articles/taiwan-the-worlds-geniuses-of-garbage-disposal-1463519134

12. Coittone, G. R. (2006). Disaster Medicine, 889.

13. Columbia University. (1988). Columbia University. Recuperado el 17 de september de 2016, de http://faculty.washington.edu/mkalton/

14. Crook, S. (1 de mars de 2016). TAIWAN TODAY. Recuperado el 1 de december de 2016, de http://taiwantoday.tw/ct.asp? $\mathrm{xItem}=242149 \& \mathrm{ctNode}=2235 \& \mathrm{mp}=9$

15. Crudata. (s.f.). Crudata Temperature. Obtenido de https://crudata.uea.ac.uk/cru/data/temperature/

16. EnergyStar. (s.f.). (E. S. Partners, Productor) Recuperado el 22 de november de 2016, de https://www.energystar.gov/index.cfm?c=partners.intl_implementation\#taiwan

17. Environmental Protection Administration Executive Yuan R.O.C. (s.f.). Recuperado el 29 de november de 2016, de http://web.epa.gov.tw/en/epashow.aspx?list=9044\&path=9055\&guid=da6d766e-4053-4dc9896d-c85421f2b5b6\&lang=en-us 
18. Environmental Protection Administration Executive Yuan R.O.C. (april de 2012). Recuperado el 29 de october de 2016, de http://www.epa.gov.tw/public/Data/4361121471.pdf

19. EPA. (october de 2012). EPA. Recuperado el 19 de october de 2016, de https://www.epa.gov/sites/production/files/2014-05/documents/handout-11-tracking.pdf

20. EPA US. (s.f.). Recuperado el 2 de december de 2016, de https://www.epa.gov/internationalcooperation/collaboration-environmental-protection-administration-taiwan-epat

21. Executive Yuan Public of China (Taiwan). (s.f.). Recuperado el 29 de november de 2016, de http://www.ey.gov.tw/en/cp.aspx?n=0775D186E2307F53

22. Federacion Internacional de Sociedades de la Cruz Roja y de la Media Luna Roja. (s.f.). Recuperado el 29 de september de 2016, de Federación Internacipnal de Sociedades de la Cruz Roja y de la Media Luna Roja. Peligroshttp://www.ifrc.org/es/introduccion/disaster-management/sobre-desastres/definicion-depeligro/tormentas-tropicales-huracanes-ciclones-y-tifones/

23. FORBES. (s.f.). Obtenido de http://www.forbes.es/actualizacion/5426/las-15-ciudades-con-mayorcalidad-de-vida-en-2016/2

24. Green Loiving. (s.f.). Green Living. Recuperado el 2 de december de 2016, de https://greenliving.epa.gov.tw/GreenLife/eng/e-greenmark.aspx

25. Ho, P. (2013). GREENING INDUSTRIES IN NEWLY INDUSTRIALIZING ECONOMIES: Asian-Style Leapfrogging. New York, United States: Routelage Taylor \& Francis Group.

26. Huang, C. (2009). The Challenge of a New Democracy to an old Civilization, Taiwan in Transformation 1895-2005. United States: Transaction Publishers.

27. Informed, R. P. (s.f.). Recuperado el 30 de september de 2016, de https://www.ready.gov/drought

28. Informed, R. P. (s.f.). Recuperado el 1 de december de 2016, de https://www.ready.gov/tsunamis

29. Informed, R. P. (s.f.). Recuperado el 1 de december de 2016, de https://www.ready.gov/heat

30. Informed, R. P. (s.f.). Recuperado el 10 de november de 2016, de https://www.ready.gov/wildfires

31. Informed, R. P. (s.f.). Recuperado el 24 de october de 2016, de https://www.ready.gov/landslides-debrisflow.

32. Informed, R. P. (s.f.). Recuperado el 26 de october de 2016, de https://www.ready.gov/biological-threats

33. Informed, R. P. (s.f.). Recuperado el 28 de october de 2016, de https://www.ready.gov/chemical-threats

34. Informed, R. P. (s.f.). Recuperado el 23 de october de 2016, de https://www.ready.gov/cyber-attack

35. Informed, R. P. (s.f.). Recuperado el 23 de october de 2016, de https://www.ready.gov/explosions

36. Informed, R. P. (s.f.). Recuperado el 28 de october de 2016, de https://www.ready.gov/hazardousmaterials-incidents

37. Informed, R. P. (s.f.). Radiological Dispersion Device. Recuperado el 28 de october de 2016, de https://www.ready.gov/radiological-dispersion-device

38. JAPAN, H. (2011). Obtenido de http://www.gov-online.go.jp/pdf/hlj/20110201/18-19.pdf

39. Kuo, Y. (2015). Policy Analysis in Taiwan. International Library of Pilicy Analysis, 5, 10-12.

40. M.F. Lu, J. J. (2014). Variation od Indoor Air Quality among Urban Public Venues in Kaohsiung City, Taiwan. Advanced Materials Research, 838-841, 1928-1933.

41. Mark, E. (1993). Three thousand years of unsustainable growth: China's environment from archaic times to the present. Australia: Institute of Advances Studies, Australian National University.

42. Mathews, H. M.-c. (1 de october de 2016). Taiwan's Green Shift-prospects and challenges. The AsiaPacific Journal. Obtenido de https://apjjf.org/2016/19/Hu.html

43. MERCER. (23 de february de 2016). Obtenido de https://www.mercer.com/newsroom/western-europeancities-top-quality-of-living-ranking-mercer.html?_ga=1.212447188.1769194345.1481476623

44. MUNDIALES, INSTITUTO DE RECURSOS. (s.f.). INSTITUTO DE RECURSOS MUNDIALES. Recuperado el 2 de november de 2016, de www.wrirosscities.org/

45. Nacioneds Unidas. (s.f.). Naciones Unidas. Recuperado el 1 de december de 2016, de www.un.org/fr/millenniumgoals/

46. Naciones Unidas. (s.f.). Naciones Unidas. Recuperado el 18 de november de 2016, de https://sustainabledevelopment.un.org/agenda21_spanish/?utm_source=OldRedirect\&utm_medium=redi rect\&utm_content=dsd\&utm_campaign=OldRedirect

47. Naciones Unidas. (s.f.). Naciones Unidas. Recuperado el 20 de noviembre de 2016, de www.un.org/esa/earthsummit/

48. Naciones Unidas. (s.f.). Naciones Unidas. Recuperado el 5 de october de 2016, de http://www.un.org/spanish/conferences/wssd/ 
49. Naciones Unidas. (s.f.). Naciones Unidas. Recuperado el 12 de october de 2016, de http://unfccc.int/portal_francophone/items/3072.php

50. Naciones Unidas. (s.f.). Naciones Unidas. Recuperado el 18 de september de 2016, de www.un.org/es/sustainablefuture/about.shtml

51. National Develpoment Council. (2106). Emerging Energy Industries: 1 Photovoltaic (PV) Industry 2. Wind Power Industry. Director, Taipei. Recuperado el 28 de november de 2016

52. NATIONAL SEVERE STORMS IABORATORY NASSL. (s.f.). Recuperado el 15 de november de 2016, de The National Severe Storms Laboratory NSSL. SEVERE http://www.nssl.noaa.gov/education/svrwx101/wind/

53. NATIONAL SEVERE STORMS LABORATORY NSSL. (s.f.). Recuperado el 15 de october de 2016, de http://www.nssl.noaa.gov/education/svrwx101/floods/

54. NATIONAL SEVERE STORMS LABORATORY NSSL. (s.f.). Recuperado el 21 de october de 2016, de : http://www.nssl.noaa.gov/education/svrwx101/hail/

55. NATIONAL SEVERE STORMS LABORATORY NSSL. (s.f.). Recuperado el 22 de september de 2016, de http://www.nssl.noaa.gov/education/svrwx101/thunderstorms/

56. NATIONAL SEVERE STORMS LABORATORY NSSL. (s.f.). Recuperado el 14 de october de 2016, de www.nssl.noaa.gov/education/svrwx101/winter/

57. NOTICIAS DE TAIWAN. (2018). Gogoro y Yamaha firmarán acuerdo para desarrollar motocicletas inteligentes. OFICIAL. Obtenido https://noticias.nat.gov.tw/news.php?post=141584\&unit=95\&utm_source=Noticias\%20de\%20Taiwan\% 205\&utm_medium=email\&utm_content=Econom\%C3\%ADa\%20textlink

58. NOTICIAS DE TAIWAN. (2018). Motocicletas eléctricas la moda verde que inunda las carreteras de Taiwan. Oficial, Taipei. Obtenido de https://noticias.nat.gov.tw/news.php?post=139653\&unit=95\&utm_source=Noticias\%20de\%20Taiwan\% 205\&utm_medium=email\&utm_content=Econom\%C3\%ADa\%20textlink

59. Organization, W. H. (2018). WHO Global Ambient Air Quality Database (update 2018). Obtenido de http://www.who.int/airpollution/data/cities/en/

60. Pandemic, R. P. (s.f.). Recuperado el 30 de october de 2016, de https://www.ready.gov/pandemic

61. Public Construction Commission Executive Yuan. (s.f.). Recuperado el 1 de december de 2016, de http://lawweb.pcc.gov.tw/EngLawContent.aspx?id=12

62. Ready Plan Stay Informed. (s.f.). Ready Plan Stay Informed. Recuperado el 3 de december de 2016, de https://www.ready.gov/earthquakes

63. RESTORE YOUR ECONOMY. (s.f.). Recuperado el 3 de december de 2016, de RESTORE YOUR ECONOMY http://restoreyoureconomy.org/disaster-overview/types-of-disasters/

64. Rodríguez, M. (2016). Concept of city. Completion of the Appendix, as part of the Student Investigative Training process. The support, made by with the support of Professor Oscar Gómez, Researcher with doctorate in Social Sciences and the Professor Fernando Alonso Ojeda, Pilot of Colombia University, Bogotá.

65. Show, T. T. (s.f.). Green Taiwan. Recuperado el 2 de december de 2016, de https://www.greentaiwan.tw/en_US/show/info.html?id=285532B08D7D6FE0D0636733C6861689

66. Siemens. (2010). Obtenido de http://www.siemens.com/press/pool/de/events/corporate/2010-11lam/Study-Latin-American-Green-City-Index_spain.pdf

67. TAIWAN REPUBLIC OF CHINA: Taipei Economic and Cultural Representative Office. (31 de december de 2015). TAIWAN REPUBLIC OF CHINA: Taipei Economic and Cultural Representative Office. Recuperado el 28 de september de 2016, de www.roc-taiwan.org/us_en/post/4977.html

68. TAIWAN TODAY. (26 de jun de 2012). TAIWAN TODAY. Recuperado el 5 de november de 2016, de http://www.taiwantoday.tw/ct.asp?xItem $=192677 \& \mathrm{ctNode}=145$

69. TEPA. (2010). Environment Policy Montly Newsletter. september.

70. The USGS Water Science School. (s.f.). Recuperado el 30 de october de 2016, de Recuperado de: http://water.usgs.gov/edu/sinkholes.html

71. U.S. Congress, O. o. (1995). Agriculture, Trade, and Environment: Achieving Complementary Policies. Washington D.C.: U.S. Government Printing Office.

72. U.S. DEPARTMENT OF SECURITY HOMELAND- FEMA. (2004). “Are You Ready? An In-Depth Guide to Citizen Preparedness. Federal Emergency Management Agency. 
73. UNFCC. (s.f.). UNFCC. Recuperado el 28 de november de 2016, de http://unfccc.int/files/kyoto_protocol/status_of_ratification/application/pdf/kp_ratification.pdf

74. USDA. (s.f.). Recuperado el 4 de december de 2016, de Bill Forum Comment Summary \& Bakground. AGRICULTURAL

PESTS

AND

DIShttp://www.usda.gov/documents/AGRICULTURAL_PESTS_AND_DISEASES.pdf

75. White, C. J. (2006). doi:1029/2005GL024826

76. World Wildlife Fund WWF. (2016). World Wildlife Fund WWF. Recuperado el 10 de october de 2016, de https://www.worldwildlife.org/pages/living-planet-report-2016

77. Yao, X. (2001). El confucionismo. Cambridge University.

\section{Appendix A}

Concept of City

In the world, there are a large number of authors who have tackled the theme of the city, there are texts from the twentieth century to date, which allow us to understand that there are no great similarities and that the theme of the city can be approached from various fully valid criteria, (Rodríguez, 2016).

\section{Etymologically which is a city}

The city concept comes from the Latin "civitas", which refers to the word citizenship where to follow a historical and based on texts that time investigated on order, citizenship is what makes the citizen which would guarantee certain full rights (BERMUDO, 2001).

The concept in Latin "civitas" refers to all citizens, where the word urbanism Latin urbs plays a very important role because at that time it referred to the city as such, the one built by the public infrastructure which as as stated above it is what creates the concept of city or urban in Latin.

\section{Prototypes for City Watch}

By verifying it in this way it can be said that the main aspect in a city is that it is clear its constant interrelation with its surroundings which must have premises; a great emphasis on social issues, environmental and economic value creation by means of their capacity to create, innovate and achieve self-sustainability which must be supported by government policies and legislation (JAPAN, 2011).

As it has been possible to identify the cities must tend towards a process of sustainability and mutual collaboration. As clear examples to be highlighted, cities such as Basel (Switzerland) where in 1998 subsidies granted by the government took the initiative to install covered over all buildings for a period of one year (Bataller, s.f.).

This city is Curitiba (Brazil), which is cataloged as the best in sustainability due to its transit bus system fast (BRT), and also with the first great pedestrian avenue of Brazil leaving her with a rating of "well above average" (Siemens, 2010).

On the other hand, Sao Paulo (Brazil) has made a great effort to generate electricity from methane gas that comes from landfills together with the case of Belo Horizonte, which according to the research carried out in 2010 by the Economist Intelligence Unit is a city Brazil as the leader in solar energy in Brazil and has a of 12 times more solar collectors per person across the country (Siemens, 2010) .

In the issue of quality of life, there are cities that stand out. With the highest quality of life in 2016, will bring their first three exponents to analyze their actions (FORBES, s.f.). First is the city of Vienna (Austria). It is said that a primary factor in this city is citizen security accompanied by the price and the quality of housing. In second place is Zurich (Switzerland), in which it is validate the cost of the products of the family basket, the price of housing and pollution in general (MERCER, 2016). Finally, there is the Auckland, New Zealand who have as first characteristics the education, consumer goods and housing (BBC MUNDO, 2016). 